\title{
Seasonal dynamics of cyanobacteria in a eutrophic reservoir (Arcoverde) in a semi-arid region of Brazil
}

\author{
Bittencourt-Oliveira, MC. ${ }^{a, b} *$, Dias, SN. ${ }^{b}$ Moura, AN. ${ }^{b}$, \\ Cordeiro-Araújo, $M K^{b}{ }^{b}$ and Dantas, $E W^{c}$

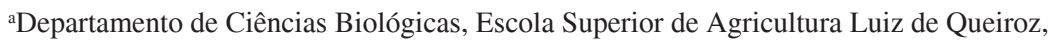
Universidade de São Paulo - USP, Av. Pádua Dias 11, CEP 13418-900, Piracicaba, SP, Brazil

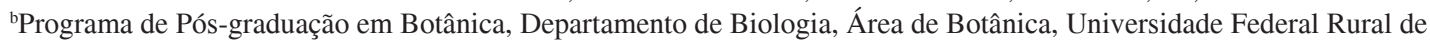
Pernambuco - UFRPE, Rua D. Manoel de Medeiros, s/n, Dois Irmãos, CEP 52171-030, Recife, PE, Brazil

'Departamento de Ciências Biológicas, Universidade Estadual da Paraíba - UEPB, Rua Horácio Trajano, s/n, Cristo, CEP 58070-450, João Pessoa, PB, Brazil

*e-mail: mbitt@usp.br
\end{abstract}

Received September 2, 2011 - Accepted October 21, 2011 - Distributed August 31, 2012 (With 3 figures)

\begin{abstract}
Environmental conditions favor the predominance of dense populations of cyanobacteria in reservoirs in northeastern Brazil. The aim of this study was to understand cyanobacterial population dynamics in the rainy and dry seasons at two depths in the Arcoverde reservoir. Microalgae and cyanobacteria samples were collected during 24 hours with intervals of 4 hours (nycthemeral) at sub-surface and $10 \mathrm{~m}$ using a van Dorn bottle and a determined biomass. Physical and chemical variables were obtained and the data were analyzed using the principal component analysis (PCA). No nycthemeral variations in the taxonomic composition or distribution of the populations of cyanobacteria were found between the different times of day in either the rainy or dry season. In both seasons, the greatest biomass of the phytoplankton community was made up of cyanobacteria at two depths and all times of the day. Cylindrospermopsis raciborskii (Woloszynska) Seenayya et Subba Raju was dominant at all times of the day on both the surface and at the bottom. In the rainy season, the differences in cyanobacterial biomass between the surface and bottom were less significant than in the dry season. The differences in cyanobacterial biomass between surface and bottom were less pronounced than those found in the dry season. We concluded that a) physical variables better explain the alterations of species in the phytoplankton community in an environment dominated by cyanobacteria throughout the year; b) seasonal climatic factors associated to periods of stratification and de-stratification are important for alterations in the community and variations in biomass and, c) the turbidity caused by rainfall favored the emergence and establishment of other cyanobacteria, especially Planktothrix agardhii (Gomont) Anagnostidis \& Komárek.
\end{abstract}

Keywords: cyanobacteria, northeast of Brazil, nycthemeral, phytoplankton, seasonal dynamics.

\section{Dinâmica sazonal de cianobactérias em um reservatório eutrófico (Arcoverde) no semiárido brasileiro}

\begin{abstract}
Resumo
As condições ambientais favorecem a predominância de populações densas de cianobactérias no nordeste do Brasil. O objetivo deste estudo foi entender a dinâmica das populações de cianobactérias nas estações seca e chuvosa, em duas profundidades, no reservatório de Arcoverde. Amostras de microalgas e cianobactérias foram coletadas durante 24 horas em intervalos de quatro horas (nictemerais) na subsuperfície e em $10 \mathrm{~m}$, com uma garrafa de van Dorn, para a determinação da biomassa. Variáveis físicas e químicas foram obtidas, e os dados investigados por meio da Análise de Componentes Principais (ACP). Não foram encontradas variações nictemerais na composição taxonômica ou na distribuição das populações de cianobactérias entre os diferentes horários do dia, bem como entre as estações seca e chuvosa. Em ambas as estações, horários do dia e profundidades amostrais, a maior biomassa da comunidade fitoplanctônica foi constituída por cianobactérias. Cylindrospermopsis raciborskii (Woloszynska) Seenayya et Subba Raju foi dominante em todos os horários do dia, tanto na superfície como no fundo. Na estação chuvosa, as diferenças de biomassa de cianobactérias entre superfície e fundo foram menos pronunciadas do que na estação seca. Concluímos que: a) variáveis físicas explicam melhor as alterações das espécies na comunidade fitoplanctônica em um ambiente dominado por cianobactérias durante todo o ano; b) fatores climáticos sazonais associados a períodos de estratificação e desestratificação são importantes para as alterações na comunidade e as variações na biomassa, e c) a turbidez causada pela chuva favoreceu o aparecimento e o estabelecimento de outras cianobactérias, especialmente Planktothrix agardhii (Gomont) Anagnostidis \& Komárek.
\end{abstract}

Palavras-chave: cianobactéria, nordeste do Brasil, nictemeral, fitoplâncton, dinâmica sazonal. 


\section{Introduction}

Climatic changes and water degradation have provided ecological conditions for the development of cyanobacteria in a large number of Brazilian reservoirs. There are frequent reports of cyanobacterial blooms in reservoirs in northeastern Brazil (Bouvy et al., 1999, 2000; Chellappa and Costa, 2003; Panosso et al., 2007; Chellappa et al., 2008a; Costa et al., 2006; Bittencourt-Oliveira et al., 2011a; Dantas et al., 2011; Lira et al., 2011; Moura et al., 2011). This country region has relatively uniform seasonal characteristics, such as a dry season (summer), with high temperatures and low rainfall index, and a rainy season (winter), with milder temperatures and a more intense rainfall regime.

Besides higher temperatures and luminosity intensities, the reservoirs of northeastern Brazil are often eutrophicated or hyper-eutrophicated by high concentrations of dissolved phosphorus (Bouvy et al., 2003; Chellappa et al., 2009; Dantas et al., 2011). The floristic composition of cyanobacteria in Pernambuco state is sometimes similar among reservoirs which have been studied so far as the following can often be found: $C$. raciborskii (sometimes identified as Raphidiopsis spp.), Geitlerinema amphibium (Agardh ex Gomont) Anagnostidis and species of Planktothrix, Microcystis and Aphanizomenon (sometimes identified as Anabaena). C. raciborskii may dominate some reservoirs for long periods of time (Bouvy et al., 1999, 2000; BittencourtOliveira et al., 2011a; Dantas et al., 2011).

The dynamics of phytoplankton populations or, more specifically, cyanobacteria, have been studied in a number of different reservoirs in Pernambuco state and other parts of northeastern Brazil. Studies carried out thus far have used different working strategies concerning sampling frequency, sites and depth (Bouvy et al., 1999, 2000, 2003; Chellappa and Costa, 2003; Chellappa et al., 2008a; Costa et al., 2009; Molisani et al., 2010; Bittencourt-Oliveira et al., 2011a; Dantas et al., 2011; Lira et al., 2011; Moura et al., 2011). Variations observed at short time intervals over 24-hour (nycthemeral) periods may provide important information regarding the behavior of phytoplankton populations throughout the day (Wood et al., 1976).

Dantas et al. (2011) report that when thermal stratification occurs in the dry season the populations of cyanobacteria from the Arcoverde reservoir show high biomass on the surface and a drastic reduction in biomass at the bottom of the reservoir. As de-stratified waters are common in the rainy season, there is a reduction in the cyanobacteria density, which is distributed both on the surface and at the bottom of the reservoir, but with no replacement by other groups of microalgae. In this same reservoir, the presence of cylindrospermopsin (33.3 ng. $\mathrm{g}^{-1}$ freeze-dried cells) was recorded for the first time in a sample in which C. raciborskii represented $77.5 \%$ of the cyanobacterial population, followed by G. amphibium (19.6\%) (BittencourtOliveira et al., 2011b).

Random and occasional samplings taken at the same time of the day could hide the structural dynamics of these populations throughout the day, leading to a mistaken appraisal of the reservoir. The question therefore arises as to whether the changes on distribution of cyanobacterial populations are maintained throughout a 24-hour period.

The aim of the present study was to understand cyanobacterial population dynamics in the rainy and dry seasons at two depths in the Arcoverde reservoir.

\section{Material and Methods}

\subsection{Study area and sampling procedure}

The Arcoverde reservoir ( $08^{\circ} 33^{\prime} 33^{\prime \prime} \mathrm{S}$ and $36^{\circ} 59^{\prime} 07^{\prime \prime}$ $\mathrm{W}$ ) is located in the municipality of Pedra in Pernambuco state, Brazil. This reservoir is used for the public water supply of approximately 100 thousand inhabitants in the semiarid region of the state, and has a full capacity of $16,800,000 \mathrm{~m}^{3}$ and maximum depth of $20 \mathrm{~m}$ (Pernambuco, 2000) (Figure 1).

Water samples were collected at four-hour intervals over a 24-hour period from the sub-surface and bottom (10 m, with $0 \%$ light penetration) in the dry (August 14 and 15, 2007) and rainy season (November 13 and 14, 2007). Daylight sampling was carried out at 1:30 PM, 5:30 PM, 5:30 AM, 9:30 AM and 1:30 PM and nighttime sampling at 9:30 PM and 1:30 AM.

\subsection{Climatologic and biotic/abiotic hydrologic variables}

Air temperature $\left({ }^{\circ} \mathrm{C}\right)$ and precipitation $\left(\mathrm{mm}^{3}\right)$ were obtained from the Instituto Nacional de Pesquisas Espaciais (INPE, 2008), taken by a meteorological station in the municipality of Arcoverde approximately $15 \mathrm{~km}$ far from the sampling site. Dissolved oxygen $\left(\mathrm{mg} . \mathrm{L}^{-1}\right)$ and the water temperature $\left({ }^{\circ} \mathrm{C}\right)$ were accessed using a field oximeter (Schott, Handylab OX1); while water turbidity (NTU) was measured using a turbidimeter (Hanna Instruments HI 93703). In order to establish water transparency (m) a Secchi disk was used; and the $\mathrm{pH}$ was determined using a potentiometer (Ação científica mPA-210). Total nitrogen (TN), total phosphorus (TP) and orthophosphate were analysed according to Valderrama (1981) and Strickland and Parsons (1965), respectively. The trophic state index was calculated (TSI) based on phosphorus concentrations according to Toledo Junior et al. (1983). Molar TN:TP ratio (Downing and McCauley, 1992) was used for assessing nutrient limitations, considering TN:TP $<20$ a limitation by nitrogen and TN:TP $>38$ by phosphorus (Kosten et al., 2009).

Phytoplankton samples were collected using a van Dorn bottle and preserved in $4 \%$ acetic Lugol's solution for subsequent determination of taxonomic composition and quantitative analysis. Species were identified using the relevant literature (Komárek and Anagnostidis, 1989, 1999, 2005; Krammer and Lange-Bertalot, 1991a, b; Komárek and Cronberg, 2001).The quantification of cyanobacteria and microalgae was determined from the density of cells (org. $\mathrm{mL}^{-1}$ ) of each taxon using the method proposed by Utermöhl (1958) and converted into biomass 


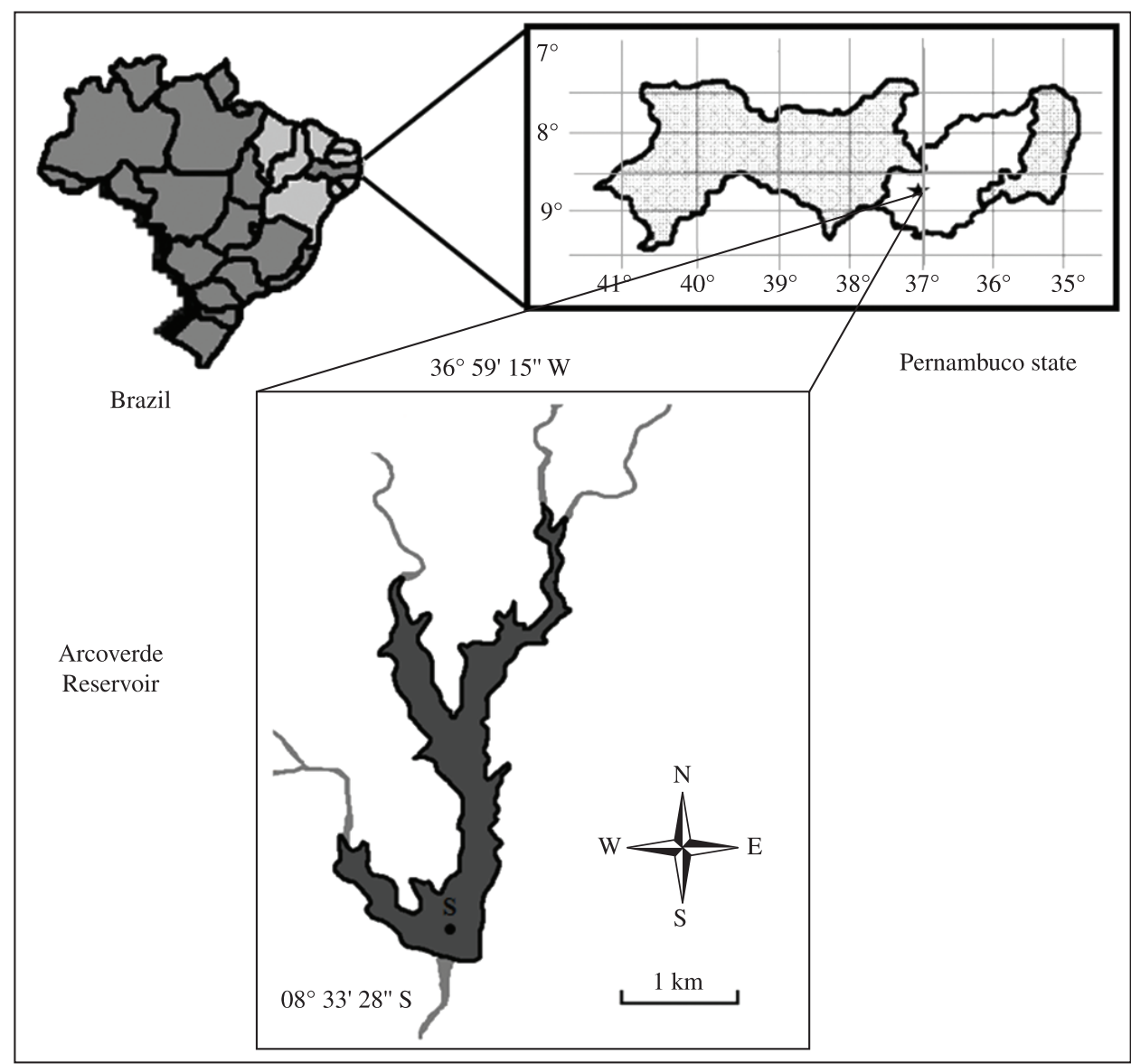

Figure 1. Geographic location of Arcoverde reservoir in northeastern Brazil. Sampling location $=\mathrm{S}$.

values $\left(\mathrm{mm}^{3} \cdot \mathrm{L}^{-1}\right)$ based on the calculation of cell volume (Hillebrand et al., 1999). Whenever possible, mean values $(n=10)$ of the cell dimensions of each taxon were used.

The classification of dominant and abundant species was based on criteria proposed by Lobo and Leighton (1986), for which a dominant species accounts for more than $50 \%$ of the total sample $\left(\mathrm{mm}^{3} \cdot \mathrm{L}^{-1}\right)$ and an abundant species has a density value above the mean value for the sample.

Variances between seasons, depths and sampling times, as well as in biotic and abiotic variables were calculated in order to determine significant differences $(\mathrm{p}<0.05)$, using the BioEstat 3.0 program (Ayres et al., 2003). Principal component analysis (PCA) was performed to determine associations between environmental variables and biotic data, using the CANOCO 4.5 program (Ter Braak and Smilauer, 1998).

\section{Results}

Air temperature and precipitation data confirmed the occurrence of two distinct seasons in the region where the Arcoverde reservoir is located. The rainy and dry seasons were characterized by mean temperatures of $19.73{ }^{\circ} \mathrm{C}$ and $23.75{ }^{\circ} \mathrm{C}$, respectively. The total rainfall was higher in the rainy season $(1.374 .65 \mathrm{~mm})$ in comparison to the dry season $(136.13 \mathrm{~mm})$.

In the rainy season, the reservoir was characterized by oxygenated waters at both depths and all times of the day, as well as thermal de-stratification and $\mathrm{pH}$ ranging from neutral to slightly alkaline (Table 1). Significant differences between depths were found with regards to water temperature $(\mathrm{F}=325.88 ; \mathrm{p}<0.00)$, dissolved oxygen $(\mathrm{F}=9.26 ; \mathrm{p}<0.02)$, total nitrogen $(\mathrm{F}=5.85 ; \mathrm{p}<0.02)$ and total dissolved phosphorus $(\mathrm{F}=6.94 ; \mathrm{p}<0.01)$. However, significant differences between depths at different times of the day were only detected for dissolved oxygen $(\mathrm{F}=9.42 ; \mathrm{p}<0.03)$.

In the dry season, the reservoir was characterized by thermally stratified water, higher temperatures in comparison to the rainy season, alkaline $\mathrm{pH}$ and low oxygen values, reaching anoxia at the bottom (Table 1). Significant differences between depths were found with regards to water temperature $(\mathrm{F}=117.07 ; \mathrm{p}<0.00)$, dissolved oxygen $(\mathrm{F}=8.59 ; \mathrm{p}<0.02)$, turbidity $(\mathrm{F}=169.13 ; \mathrm{p}<0.00), \mathrm{pH}$ $(\mathrm{F}=626.33 ; \mathrm{p}<0.00)$, total dissolved phosphorus $(\mathrm{F}=6.28$; $\mathrm{p}<0.04)$ and total phosphorus $(\mathrm{F}=9.40 ; \mathrm{p}<0.02)$. No 


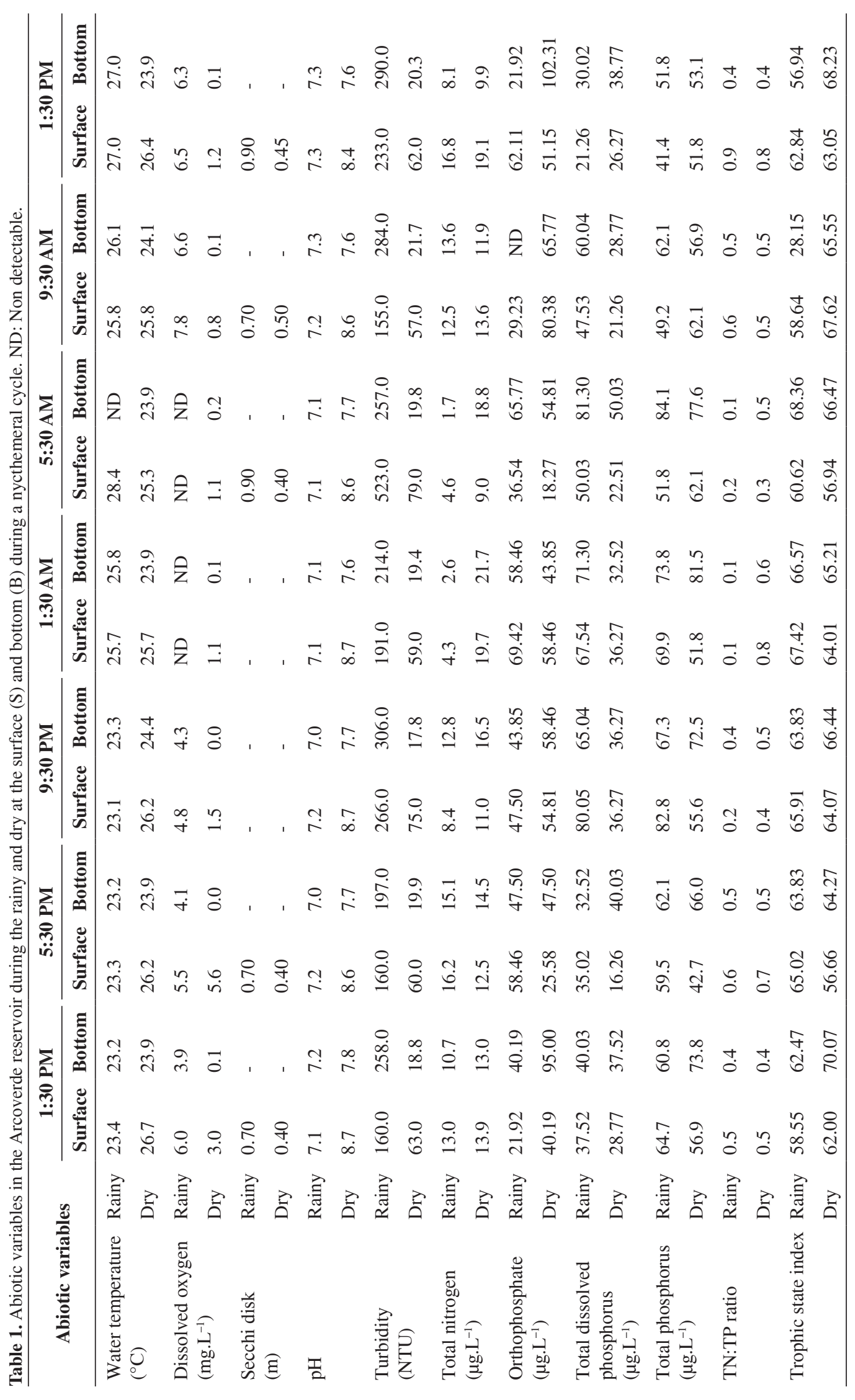


significant differences were found between the different times of the day for any of the abiotic variables.

Significant differences between seasons were found concerning dissolved oxygen $(\mathrm{F}=11.50 ; \mathrm{p}<0.00), \mathrm{pH}$ $(\mathrm{F}=52.81 ; \mathrm{p}<0.00)$, turbidity $(\mathrm{F}=64.32 ; \mathrm{p}<0.00)$, total nitrogen $(\mathrm{F}=7.21 ; \mathrm{p}<0.02)$ and total dissolved oxygen $(F=11.11 ; \mathrm{p}<0.00)$. Nitrogen limitations and high concentrations of phosphorus were found in both seasons, thereby classifying the Arcoverde reservoir as eutrophic, regardless of the season. The water was more turbid in the rainy season. Turbidity in the dry season was greater on the surface (Table 1).

No nycthemeral variations in the taxonomic composition or distribution of the populations of cyanobacteria were found between the different times of the day in either the rainy or dry seasons. Variations were only encountered in the seasonal analysis.

In both seasons, the greatest biomass of the phytoplankton community was constituted by cyanobacteria at both depths and all times of the day (Figure 2a, b). In the dry season, the cyanobacterial biomass at the surface ranged from 71.13 to $79.45 \mathrm{~mm}^{3} . \mathrm{L}^{-1}$, which was 2.5 -fold (at 5:30 PM) to 17-fold (1:30 PM on August 15) greater than that found at the bottom (4.47 to $12.99 \mathrm{~mm}^{3} . \mathrm{L}^{-1}$ ) (Table 2). Cylindrospermopsis raciborskii represented up to $94.61 \%$ of the phytoplankton biomass at the surface. C. raciborskii (coiled and straight trichomes) was dominant at all times of the day at both the surface and the bottom (Figure 2c). Geitlerinema amphibium and the Bacillariophyceae Aulacoseira granulata (Ehrenberg) Simonsen and Ulnaria ulna (Nitzsch) P. Compère in Jahn et al. were abundant (with a biomass value above the mean) at some times of the day, usually at the bottom.

In the rainy season, on the other hand, the differences in cyanobacterial biomass between surface and bottom were less significant than those found in the dry season. At times, greater biomasses were found at the bottom at some times of the day: 1:30 PM on August $14\left(3.68 \mathrm{~mm}^{3} . \mathrm{L}^{-1}\right)$, 5:30 PM (3.84 $\left.\mathrm{mm}^{3} \cdot \mathrm{L}^{-1}\right)$ and 1:30 AM (5.72 $\left.\mathrm{mm}^{3} \cdot \mathrm{L}^{-1}\right)$ (Figure 2d). With the de-stratification of the water in this season, the cyanobacterial biomass dropped substantially, ranging from 3.14 to $6.49 \mathrm{~mm}^{3} . \mathrm{L}^{-1}$ at the surface and 2.97 to $5.72 \mathrm{~mm}^{3} \cdot \mathrm{L}^{-1}(79.55 \%)$ at the bottom (Table 2). Greater biomasses of Planktothrix agardhii, G. amphibium, Merismopedia punctata Meyen were found competing with $C$. raciborskii (Figure 2d). Only P. agardhii was dominant in the rainy season at 1:30 PM (at the bottom on August 14).

The first two axes of the PCA explained $98.4 \%$ of the total variability in the biotic data and, together environmental variables, $99.4 \%$ of the biotic data. Environmental variables were highly correlated with the cyanobacterial community

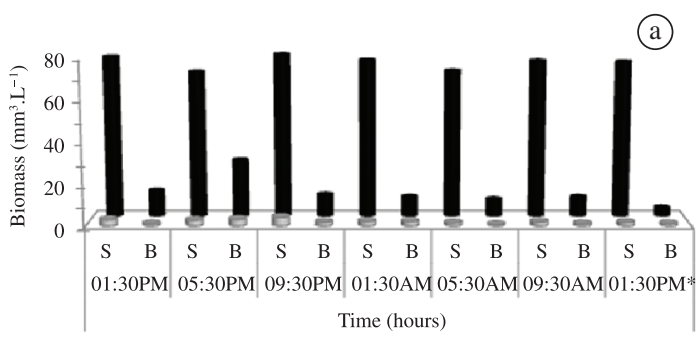

$\square$ Microalgae

- Cyanobacteria

(c)

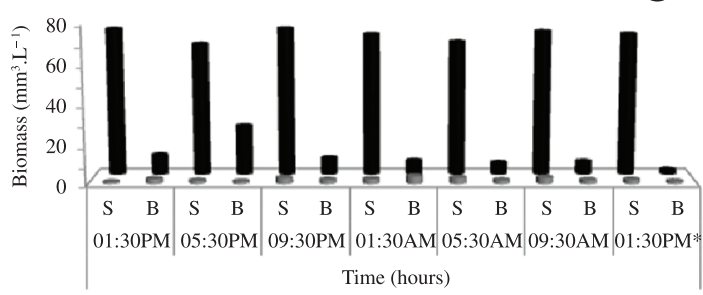

- P. agardhii

- C. raciborskii

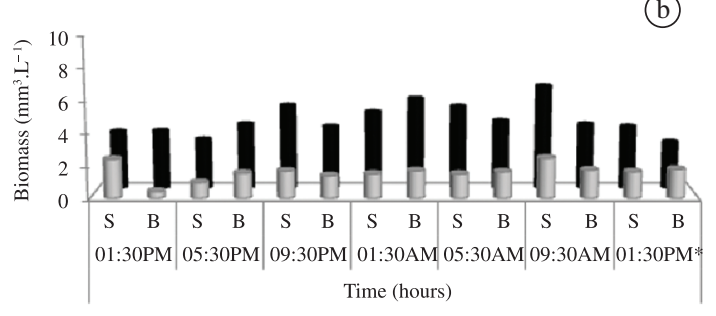

$\square$ Microalgae $=$ Cyanobacteria

(d)

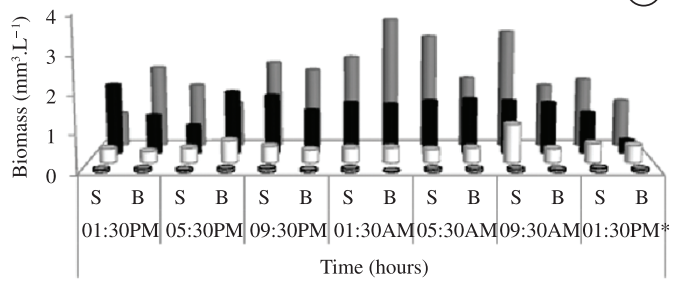

$\square$ M. punctata $\square$ G. amphibium $\quad$ C. raciborskii $\quad$ P. agardhii

Figure 2. Total biomass $\left(\mathrm{mm}^{3} \cdot \mathrm{L}^{-1}\right)$ of cyanobacteria, microalgae and the most representative species of cyanobacteria at surface (S) and bottom (B) of Arcoverde reservoir during nycthemeral sampling; a) cyanobacteria and microalgae in dry season in August 2007, $(*)=$ second day of sampling - August 15; b) cyanobacteria and microalgae rainy season in November 2007, $(*)=$ second day of sampling - November 14 ; c) The most representative cyanobacteria in dry season, $(*)=$ second day of sampling - August 15 ; d) The most representative cyanobacteria in rainy season, $(*)=$ second day of sampling - November 14. 


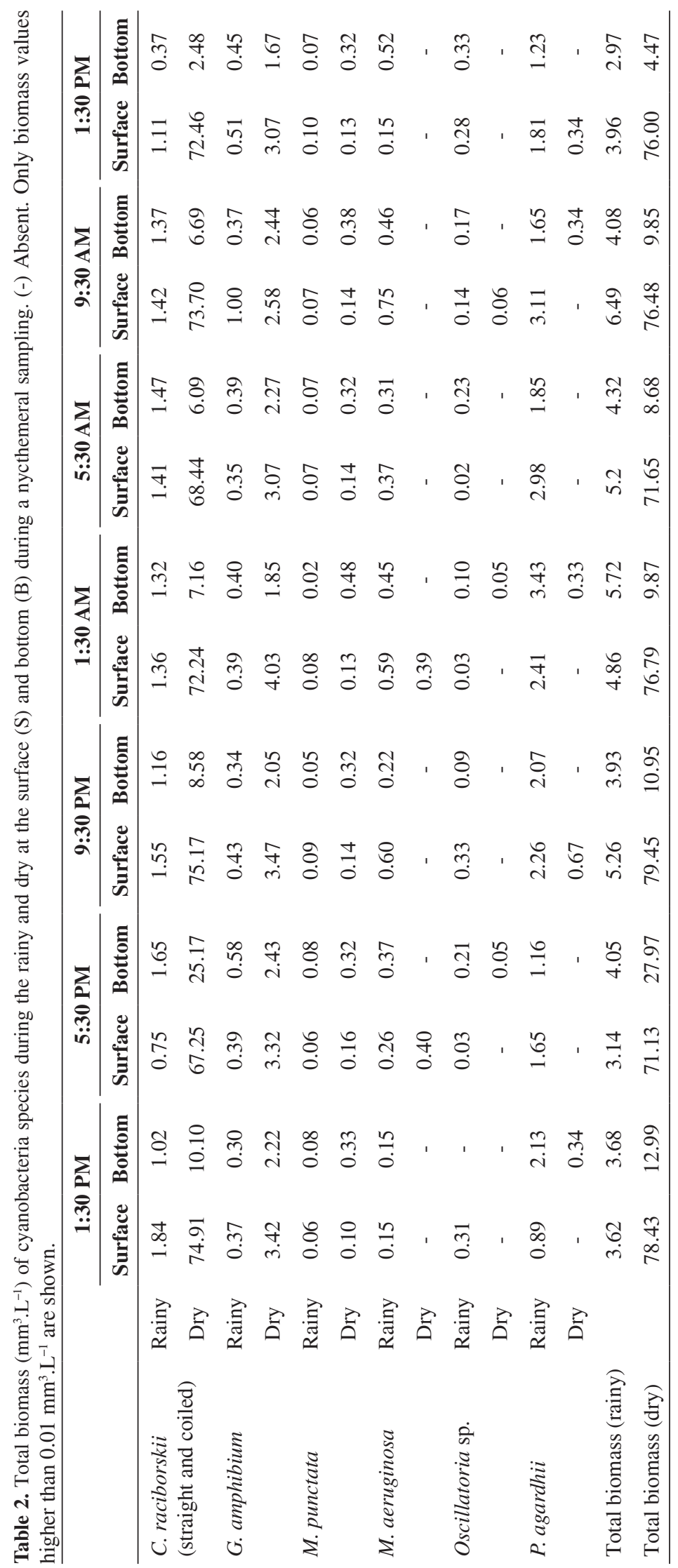


Table 3. Statistical summary and correlation coefficients between phytoplankton associations and abiotic variables on first two PCA axes in Arcoverde reservoir, Brazil.

\begin{tabular}{lcc}
\hline & Axis 1 & Axis 2 \\
\hline Eigenvalues & 0.937 & 0.048 \\
Accumulated variance in & 93.7 & 98.4 \\
biotic data (\%) & & \\
Accumulated variance in & 95.9 & 99.4 \\
association-environment & & \\
relation (\%) & & \\
Association-environment & 0.985 & 0.830 \\
correlation & & \\
& Intra-set correlation \\
& Axis 1 & Axis 2 \\
Temperature (Temp) & 0.211 & -0.062 \\
Secchi (Sec) & -0.013 & -0.294 \\
pH & 0.966 & -0.053 \\
Turbidity (Turb) & -0.690 & -0.499 \\
Orthophosphate (PO4) & 0.087 & 0.314 \\
Total nitrogen (TN) & 0.396 & 0.390 \\
Total phosphorus (TP) & -0.206 & 0.169 \\
Dissolved oxygen (DO) & -0.368 & -0.230 \\
Total dissolved Phosphorus & -0.566 & -0.282 \\
(TDP) & & \\
Nitrogen-phosphorus ratio & 0.373 & 0.197 \\
(TN/TP) & & \\
Trophic state index (TSI) & 0.106 & 0.174 \\
\hline
\end{tabular}

on both axes (Table 3). Axis 1 of PCA, representing the seasonal gradient in temperature and $\mathrm{pH}$, separated the species in relation to season and Axis 2, the species in relation to light availability (Secchi disk) (Figure 3). The PCA analysis revealed a strong correlation between cyanobacteria and environmental variables. $C$. raciborskii was highly correlated with $\mathrm{pH}$, followed by water temperature. $P$. agardhii was strongly correlated with turbidity. G. amphibium and M. punctata were correlated with total nitrogen availability, the TN:TP ratio and orthophosphate.

\section{Discussion}

The Arcoverde reservoir is located in the semiarid region of Pernambuco state. It has typical characteristics of a eutrophic environment throughout the year, such as high water temperature and light intensities, high concentrations of phosphates and low nitrogen/phosphorus ratio (Bouvy et al., 1999, 2001; Moura et al., 2011).

Dominance alternation in the Arcoverde reservoir was seen during the two different seasons. In the dry season, C. raciborskii dominated the phytoplankton at both depths and all times of the day, with biomass values ranging from 2.48 to $75.17 \mathrm{~mm}^{3} . \mathrm{L}^{-1}$. The largest biomass was concentrated at the surface (Figure 2a). The principal component analysis (PCA) indicated that the cyanobacterial community in this season was mainly influenced by water temperature and $\mathrm{pH}$.

In the rainy season, $P$. agardhii behaved as the dominant species. G. amphibium also took part in the phytoplankton composition, but with lower biomass values (Figure 2d, Table 2 and 3 ) than those of $C$. raciborskii, which maintained stable populations, although on a smaller scale. PCA revealed that $G$. amphibium was mainly favored by the increase in turbidity in this season, which improved its competition with $C$. raciborskii. Moreover, the reduction in the biomass of $C$. raciborskii made the development of other species of cyanobacteria possible, which were favored by the competition. Kokocisnki et al. (2010) reported greater development of $P$. agardhii associated to a high degree of turbidity in hyper-trophic lakes in Poland, as was seen in the Arcoverde reservoir. In the rainy season, the input of allochthonous matter from agriculture and sewage residue brought by rain and the water mixing up to sediment bottom increase turbidity, thereby favoring succession processes among phytoplankton (Figueredo and Giani, 2001; Chellappa et al., 2008b).

C. raciborskii in the Francs-Pêucheurs lake in France was correlated with high TN/TP ratios (Briand et al., 2002). Studying lakes in the Scharmützelsee region in Germany, Rücker et al. (1997) suggest that $P$. agardhii is favored by low TN/TP ratios. Huszar et al. (2000) studying five reservoirs in Brazil found that non-heterocystous cyanobacteria were also correlated with low TN/TP ratios.

In the Arcoverde reservoir, the highest TN/TP ratios were found in the dry season (at seven different times of the day), together with the dominance of $C$. raciborskii. Although the TN/TP ratio is not considered the most important factor to the development of C. raciborskii, PCA also showed this ratio to be correlated with the dry season. In the present study, C. raciborskii and P. agardhii alternated in terms of the dominance of the biomass in the two seasons investigated, similarly with findings reported by Rücker et al. (1997), Huszar et al. (2000) and Briand et al. (2002).

C. raciborskii and $P$. agardhii are widely distributed in the tropics. However, $C$. raciborskii has become an invading species in recent decades, with broad distribution throughout the world and easily dominating the phytoplankton community under adequate conditions (Padisák, 1997; Saker et al., 2003; Mack et al., 2000; Burford and Davis, 2011). Both species are potential toxin producers and therefore constitute a concern for authorities that monitor the quality of public drinking water (Lagos et al., 1999; Pomati et al., 2000; Kokocinski et al., 2010).

The ecological success of $C$. raciborskii in freshwater environments may be related to migration capacity in the water column, tolerance to variations in light availability, and its ability to fix inorganic carbon at high $\mathrm{pH}$ values or the direct use of bicarbonates as a source of carbon (Golterman et al., 1978; Chellappa et al., 2008b). This species also has the ability to fix atmospheric $\mathrm{N}_{2}$, which gives it an adaptive advantage in environments with low nitrogen availability (Dokulil and Teubner, 2000). 


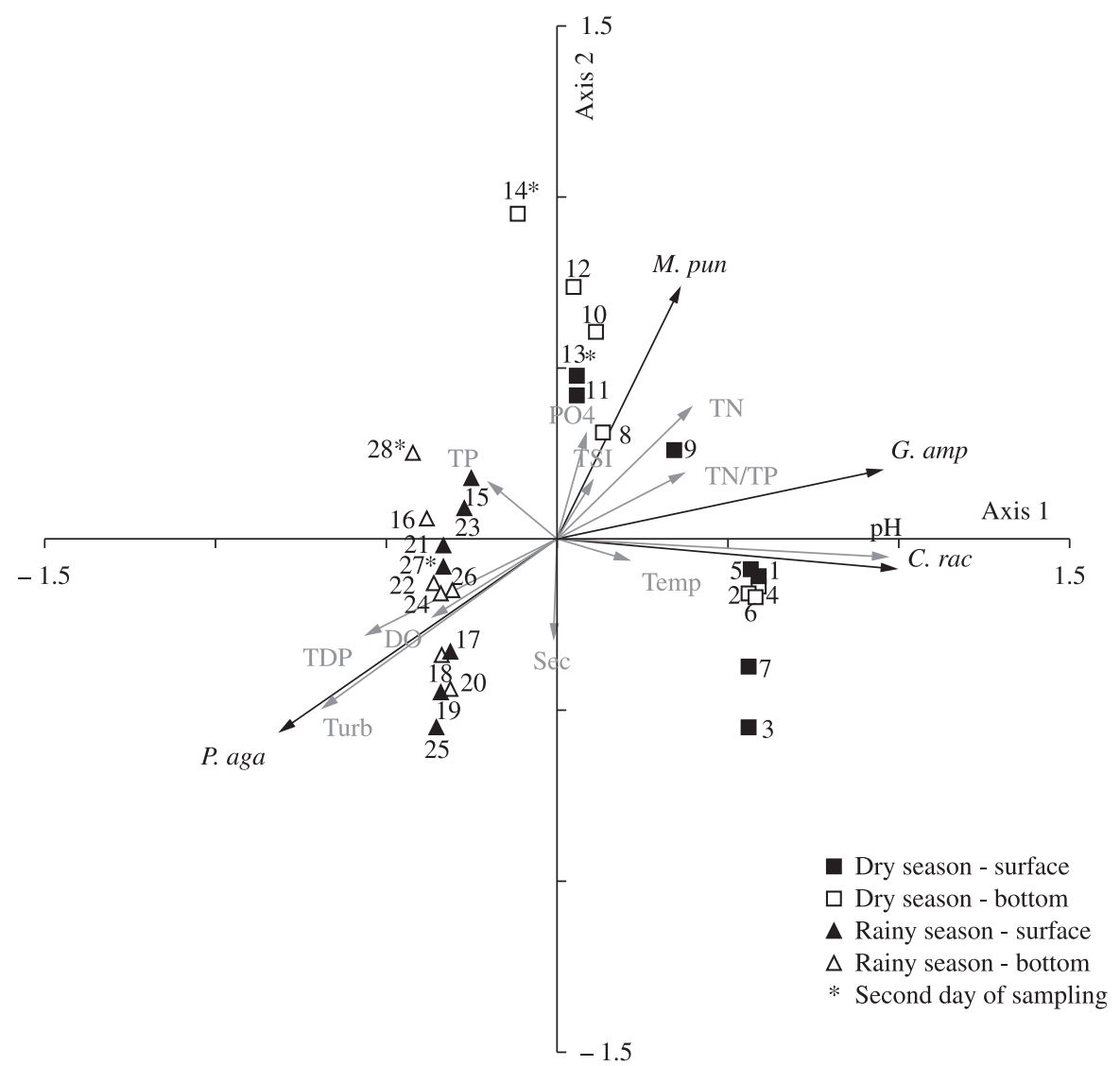

Figure 3. PCA ordination diagram showing seasonal periods, environmental variables and species with most representative biomass in Arcoverde reservoir; C.rac. = C. raciborskii; G.amp. = G. amphibium; M.pun. = M. punctata $;$ P.aga. $=$ P. agardhii; $\mathrm{TP}=$ total phosphorus; $\mathrm{TN}=$ total nitrogen; Turb. = turbidity; Temp. = water temperature; $\mathrm{DO}=$ dissolved oxygen; $\mathrm{TDP}=$ total dissolved phosphorus; Sec. $=$ Secchi disk; PO4 = orthophosphate; TN/TP = nitrogen/phosphorus ratio; TSI = trophic state index; 1 = 1:30 PM dry surface; 2 = 1:30 PM dry bottom; 3 = 5:30 PM dry surface; 4 = 5:30 PM dry bottom; 5 = 9:30 PM dry surface; $6=9: 30$ PM dry bottom; $7=1: 30$ AM dry surface; $8=1: 30$ AM dry bottom; $9=5: 30$ AM dry surface; 10 = 5:30 AM dry bottom; 11 = 9:30 AM dry surface; 12 = 9:30 AM dry bottom; $13=13: 30$ PM dry surface; $14=13: 30$ PM dry bottom; $15=1: 30 \mathrm{PM}$ rainy surface; $16=1: 30 \mathrm{PM}$ rainy bottom; $17=5: 30 \mathrm{PM}$ rainy surface; $18=5: 30 \mathrm{PM}$ rainy bottom; 19 = 9:30 PM rainy surface; $20=9: 30 \mathrm{PM}$ rainy bottom; $21=1: 30 \mathrm{AM}$ rainy surface; $22=1: 30$ AM rainy bottom; $23=5: 30$ AM rainy surface; $24=5: 30$ AM rainy bottom; $25=9: 30$ AM rainy surface; $26=9: 30$ AM rainy bottom; 27 = 1:30 PM rainy surface; $28=1: 30$ PM rainy bottom; $(*)=$ second day of sampling.

Bittencourt-Oliveira et al. (2011a) studying the behavior of C. raciborskii (straight and coiled morphotypes) at different depths under different temperature and light intensity conditions (characteristics of the dry and rainy seasons), observed that both morphotypes demonstrated adaptability to these environmental variables, but preferred a lesser light intensity and milder temperatures, which are characteristics of the rainy season in the semi-arid region.

Some studies also suggest that $C$. raciborskii would benefit from low light intensities (Padisák and Reynolds, 1998; Reynolds et al., 2002; Bittencourt-Oliveira et al., 2011a; Burford and Davis, 2011). In laboratory experiments, Briand et al. (2004) found no statistically significant differences in the growth rate of different strains of C. raciborskii. In batch cultures, Bittencourt-Oliveira et al. (2012) analyzed the effects of the combination of two different light intensities and temperatures on the growth rate of the straight and coiled trichomes of $C$. raciborskii strains and found that both morphtypes showed faster growth rates when submitted to higher light intensity and temperature, whereas the condition of a lower temperature and higher light intensity had a negative effect on the development of both morphotypes. Unlike the strains analyzed by Briand et al. (2004), the Brazilian strains (coiled and straight) responded differently to the temperatures and light intensities tested. These apparently contradictory data lead us to hypothesize that there are no generalizations regarding the behavior of $C$. raciborskii populations in different regions. There are indications that $C$. raciborskii populations exhibit differentiated physiologic behavior, which should be taken into consideration in the interpretation of data. 
C. raciborskii can be dominant throughout the year (Padisák, 1997), but is generally more restricted to dry periods with low rainfall (Chellappa and Costa, 2003) and high temperatures (Bouvy et al., 2006). The stability of the water column (Berger et al., 2006) and the long period of water retention during dry periods in the reservoirs provide excellent conditions of temperature and irradiation for the dominance of this species (Bouvy et al., 2000). A vertical variation in temperature also affects the availability of nutrients and is a determining factor in the seasonal dynamics of phytoplankton (Becker et al., 2009). Dantas et al. (2011) previously reported an increase in $C$. raciborskii populations in stratified waters in the Arcoverde and Pedra reservoirs.

Thermal stratification and $\mathrm{pH}$ between the surface and bottom in the dry season seems to favor C. raciborskii at all depths and times of the day. Thermal stratification in the dry season (summer) and de-stratification in the rainy season (winter) have also been demonstrated in other studies carried out in semiarid regions of northeastern Brazil (Bouvy et al., 1999, 2000; Chellappa and Costa, 2003; Bittencourt-Oliveira et al., 2011a; Dantas et al., 2011). According to Bouvy et al. (2000), the development of this species is frequent in reservoirs in the semiarid region of Brazil, as most are shallow bodies of water with considerable stability in the water column, as well as high $\mathrm{pH}$ and temperature values.

The favoring of $C$. raciborskii by stratification cannot be considered a rule. Bittencourt-Oliveira et al. (2011a) in the Mundaú reservoir in northeastern Brazil reported that populations of $C$. raciborskii (coiled and straight morphotypes) increased in density under conditions of thermal de-stratification in comparison to the stratification found in the dry season. The period of de-stratification was associated to lower light intensities and temperatures than in the period of stratification, providing more adequate conditions for growth. Moreover, the species dominated throughout the year, without the presence of other cyanobacteria. Similar results, with $C$. raciborskii dominating under conditions of de-stratification are reported in shallow polymictic ecosystems or with a constant isothermal water column in tropical reservoirs (Bouvy et al., 2003; Dantas et al., 2011).

P. agardhii can grow at low temperatures in temperate (Dokulil and Teubner, 2000; Kokocinski et al., 2010) and eutrophic lakes even in winter (Poulickova et al., 2004). This species is associated to turbid waters with a high disturbance frequency (Scheffer et al., 1997; Nixdorf et al., 2003). According to Kokocinski et al. (2010), the abundance of Planktothrix is negatively related to that of $C$. raciborskii and favored by conditions of greater turbidity and higher concentrations of phosphorus, whereas $C$. raciborskii is related to ammonium nitrogen, with a preference for warm, less turbid waters. In the Arcoverde reservoir the greater development of $P$. agardhii was related to an increase in turbidity and concentrations of total dissolved phosphorus. Populations of P. agardhii and C. raciborskii were negatively related, with the prevalence of one or the other species in one of the seasonal periods favored by the established physical and chemical conditions.
According to PCA, physical variables were more significant to determine the greater biomasses and success of $C$. raciborskii and $P$. agardhii in each period in relation to the availability of nutrients. Naselli-Flores et al. (2000) studying 21 oligotrophic to hypertrophic reservoirs reported that the availability of nutrients tends to exert a greater influence over the composition of phytoplankton species in environments in which this availability is limiting, as in the case of oligotrophic reservoirs. In eutrophic reservoirs, such as the Arcoverde reservoir, physical factors induced by trophic and seasonal gradients are more important and affect the normal patterns of variability.

\section{Conclusions}

In the Arcoverde reservoir: a) physical variables better explain the alterations of species in the phytoplankton community in an environment dominated by cyanobacteria throughout the year; b) seasonal climatic factors associated to periods of stratification and de-stratification are important for alterations in the community and variations in biomass; c) the turbidity caused by rainfall favored the emergence and establishment of other cyanobacteria, especially $P$. agardhii and d) phytoplankton variations in biomass and composition are tenuous throughout the day, with some exceptions, but do not differ substantially from the values found with spot sampling performed at the same time of the day in the Arcoverde reservoir.

Acknowledgements - This study was supported by grants from CAPES (Coordenação de Aperfeiçoamento de Pessoal de Nível Superior) and CNPQ - Brazilian agencies for the promotion of Science.

\section{References}

AYRES, M., AYRES JUNIOR, M., AYRES, DL. and DOS SANTOS, AA., 2003. Software bioestat, aplicações estatísticas nas áreas das ciências biomédicas. versão 3.0. Belém: Sociedade Civil Mamirauá/MCT/CNPQ.

BECKER, V., CARDOSO, LS. and HUSZAR, VLM., 2009. Diel variation of phytoplankton functional groups in a subtropical reservoir in southern Brazil during an autumnal stratification period. Aquatic Ecology, vol. 43, no. 2, p. 285-293. http://dx.doi. org/10.1007/s10452-008-9164-0

BERGER, C., BA, N., GUGGER, M., BOUVY, M., RUSCONI, F., COUTE, A., TROUSSELLIER, M. and BERNARD, C., 2006. Seasonal dynamics and toxicity of Cylindrospermopsis raciborskii in Lake Guiers (Senegal, West Africa). FEMS Microbiology Ecology, vol. 57, no. 3, p. 355-366. PMid:16907750. http://dx.doi. org/10.1111/j.1574-6941.2006.00141.x

BITTENCOURT-OLIVEIRA, MC., BUCH, B., HEREMAN, TC., ARRUDA-NETO, JDT., MOURA, AN. and ZOCCHI, SS., 2012. Effects of light intensity and temperature on Cylindrospermopsis raciborskii (Cyanobacteria) with straight and coiled trichomes: growth rate and morphology. Brazilian Journal of Biology, vol. 72, no. 2, p. 343-351. http://dx.doi.org/10.1590/S151969842012000200016 
BITTENCOURT-OLIVEIRA, MC., MOURA, AN., HEREMAN, TC. and DANTAS, EW., 2011a. Increase in Straight and Coiled Cylindrospermopsis raciborskii (Cyanobacteria) populations under conditions of thermal de-stratification in a shallow tropical reservoir. Journal of Water Resource and Protection, vol. 3, no. 4, p. 245-252. http://dx.doi.org/10.4236/jwarp.2011.34031

BITTENCOURT-OLIVEIRA, MC., PICCIN-SANTOS, V., KUJBIDA, P. and MOURA, AN., 2011b. Cylindrospermopsin in water supply reservoirs in Brazil determined by immunochemical and molecular methods. Journal of Water Resource and Protection, vol. 3, no. 6, p. 349-355. http://dx.doi.org/10.4236/jwarp.2011.36044

BOUVY, M., FALCÃO, D., MARINHO, M., PAGANO M. and MOURA, AN., 2000. Occurrence of Cylindrospermopsis (Cyanobacteria) in 39 Brazilian tropical reservoirs during the 1998 drought. Aquatic Microbial Ecology, vol. 23, no. 1, p. 13-27.

BOUVY, M., MOLICA, RR., DE OLIVEIRA, S., MARINHO, M. and BECKER, B., 1999. Dynamics of a toxic cyanobacterial bloom (Cylindrospermopsis raciborskii) in a shallow reservoir in the semi-arid region of northeast Brazil. Aquatic Microbial Ecology, vol. 20, no. 3, 285-297. http://dx.doi.org/10.3354/ame020285

BOUVY, M., NASCIMENTO, SM., MOLICA, RJR. and FERREIRA, A., 2003. Limnological features in Tapacurá reservoir (northeast Brazil) during a severe drought. Hydrobiologia, vol. 493, no. 1-3, p. 115-130.

BOUVY, M., PAGANO, M. and TROUSSELIER, M., 2001. Effects of a cyanobacterial bloom (Cylindrospermopsis raciborskii) on bacteria and zooplankton communities in Ingazeira reservoir (northeast Brazil). Aquatic Microbial Ecology, vol. 25, no. 3, p. 215-227. http://dx.doi.org/10.3354/ame025215

BOUVY, M., BA, N., KA, S., SANE, S., PAGANO, M. and ARFI, R., 2006. Phytoplankton community structure and species assemblage succession in a shallow tropical lake (Lake Guiers, Senegal). Aquatic Microbial Ecology, vol. 45, no. 2, p. 147-161. http://dx.doi.org/10.3354/ame045147

BRIAND, JF., LEBOULANGER, C. and HUMBERT, JF., 2004. Cylindrospermopsis raciborskii (Cyanobacteria) Invasion at mid-latitudes: selection, wide physiological tolerance, or global warming? Journal of Phycology, vol. 40, no. 2, p. 231-238. http:// dx.doi.org/10.1111/j.1529-8817.2004.03118.x

BRIAND, JF., ROBILLOT, C., QUIBLIER-LIOBÉRAS, C., HUMBERT, JF., COUTÉ A. and BERNARDE, C., 2002. Environmental context of Cylindrospermopsis raciborskii (Cyanobacteria) blooms in shallow pond in France. Water Research, vol. 36, no. 13, p. 3183-3192. http://dx.doi.org/10.1016/ S0043-1354(02)00016-7

BURFORD, MA. and DAVIS, TW., 2011. Physical and chemical processes promoting dominance of the toxic cyanobacterium Cylindrospermopsis raciborskii. Chinese Journal of Oceanology and Limnology, vol. 29, no. 4, p. 883-891. http://dx.doi.org/10.1007/ s00343-011-0517-5

CHELLAPPA, NT. and COSTA, MAM., 2003. Dominant and co-existing species of cyanobacteria from an eutrophicated reservoir of Rio Grande do Norte state, Brazil. Acta Oecologica, vol. 24, no. 1, p. 3-10.

CHELLAPPA, NT., BORBA, JM. and ROCHA, O., 2008b. Phytoplankton community and physical-chemical characteristics of water in the public reservoir of Cruzeta, RN, Brazil. Brazilian
Journal of Biology, vol. 68, no. 3, p. 477-494. http://dx.doi. org/10.1590/S1519-69842008000300004

CHELLAPPA, NT., CHELLAPPA, SL. and CHELLAPPA, S., 2008a. Harmful phytoplankton blooms and fish mortality in a eutrophicated reservoir of northeast Brazil. Brazilian Archives of Biology and Technology, vol. 51, no. 4, p. 833-841.

CHELLAPPA, NT., CHELLAPPA, T., CÂMARA, FRA., ROCHA, O. and CHELLAPPA, S., 2009. Impact of stress and disturbance factors on the phytoplankton communities in northeastern Brazil reservoir. Limnologica, vol. 39, no. 4, p. 273-282. http://dx.doi. org/10.1016/j.limno.2009.06.006

COSTA, IAS., AZEVEDO, SMFO., SENNA, PAC., BERNARDO, RR., COSTA, SM. and CHELLAPPA, NT., 2006. Occurrence of toxin-producing cyanobacteria blooms in a Brazilian semiarid reservoir. Brazilian Archives of Biology and Technology, vol. 66, no. 1B, p. 211-219.

COSTA, IAS., CUNHA, SRS., PANOSSO, R., ARAÚJO, MFF., MELO, JLS. and ESKINAZI-SANT'ANNA, EM., 2009. Dinâmica de cianobactérias em reservatórios eutróficos do semiárido do Rio Grande do Norte. Oecologia Brasiliensis, vol. 13, no. 2, p. 382-401.

DANTAS, EW., MOURA, AN. and BITTENCOURT-OLIVEIRA, MC., 2011. Cyanobacterial blooms in stratified and destratified eutrophic reservoirs in semi-arid region of Brazil. Anais da Academia Brasileira de Ciências, vol. 83, no.4, p. 1327-1338. http://dx.doi.org/10.1590/S0001-37652011000400019

DOKULIL, MT. and TEUBNER, K., 2000. Cyanobacterial dominance in lakes. Hydrobiologia, vol. 438, no. 1-3, p. 1-12.

DOWNING, JA. and McCAULEY, E. 1992. The nitrogen: phosphorus relationship in lakes. Limnology and Oceanography, vol. 37, no. 5, p. 936-945. http://dx.doi.org/10.4319/1o.1992.37.5.0936

FIGUEREDO, CC. and GIANI, A. 2001. Seasonal variation in the diversity and species richness of phytoplankton in a tropical eutrophic reservoir. Hydrobiologia, vol. 445, no. 1-3, p. 165-174.

GOLTERMAN, HL., CLYMO, RS. and OHNSTAD, MAM. 1978. Methods for physical and chemical analysis of Freshwaters. IBP Oxford: Handbook Blackwell Sci. 215 p.

HILLEBRAND, H., DÜRSELEN, C., KIRSCHTEL, D., POLLINGHER, U. and ZOHARY, T., 1999. Biovolume calculation for pelagic and benthic microalgae. Journal of Phycology, vol. 35, no. 2, p. 403-424. http://dx.doi.org/10.1046/j.15298817.1999.3520403.x

HUSZAR, VLM., SILVA, LHS., MARINHO, M., DOMINGOS, P. and SANT'ANNA, CL., 2000. Cyanoprokaryote assemblages in eight productive tropical Brazilian waters. Hydrobiologia, vol. 424 , no. 1-3, p. 67-77.

Instituto Nacional de Pesquisas Espaciais - INPE, 2008. Available from: <http://satelite.cptec.inpe.br/PCD/historico/consulta_pcdm. jsp>. Access in: 13 fev. 08.

KOKOCINSKI, M., STEFANIAK, K., MANKIEWICZ-BOCZEK, J., IZYDORCZYK, K. and SOININEN, J., 2010. The ecology of the invasive cyanobacterium Cylindrospermopsis raciborskii (Nostocales, Cyanophyta) in two hypereutrophic lakes dominated by Planktothrix agardhii (Oscillatoriales, Cyanophyta). European Journal of Phycology, vol. 45, no. 4, p. 365-374. http://dx.doi.or $\mathrm{g} / 10.1080 / 09670262.2010 .492916$ 
KOMÁREK, J. and ANAGNOSTIDIS, K., 1989. Modern approach to the classification system of Cyanophytes, 4: Nostocales. Algological Studies, vol. 56, p. 247-345.

-, 1999. Cyanoprokayota 1. Teil: Chroococcales. In ETTL, H., GÄRTNER, G., HEYNING, H. and MOLLENHAUER, D. (Eds.). Süßwasserflora von Mitteleuropa 19/1. Lübeck: Gustav Fischer.

-, 2005. Cyanoprokaryota 2. Teil: Oscillatoriales. In BÜDEL, B., KRIENITZ, L., GÄRTNER, G. and SCHARGERL, M. (Eds.). Süßwasserflora von Mitteleuropa 19/2. München: Elsevier GmbH.

KOMÁREK, J. and CRONBERG, G., 2001. Some chroococcalean and oscilatorialen Cyanoprokaryotes from southern African lakes, ponds and pools. Nova Hedwigia, vol. 73, p. 129-160. PMid:19831070.

KOSTEN, S., HUSZAR, VLM., MAZZEO, N., SCHEFFER, M., STERNBERG, LSL. and JEPPESEN, E., 2009. Lake and watershed characteristics rather than climate influence nutrient limitation in shallow lakes. Ecological Applications, vol. 19, no. 7, p. 1791-1804. http://dx.doi.org/10.1890/08-0906.1

KRAMMER, K. and LANGE-BERTALOT, H., 1991a. Bacillariophyceae, 3. Teil: Centrales, Fragilariaceae, Eunotiaceae. In ETTL, H., GÄRTNER, G., HEYNING, H. and MOLLENHAUER, D. (Eds.). Süßwasserflora von Mitteleuropa 2/3. Lübeck: Gustav Fischer.

-, 1991b. Bacillariophyceae, 4. Teil: Achananthaceae, Kritische Ergänzungen zu Navicula (Lineolatae) and Gomphonema. In ETTL, H., GÄRTNER, G., HEYNING, H. and MOLLENHAUER, D. (Eds.). Süßwasserflora von Mitteleuropa 2/4. Stuttgart: Gustav Fischer Verlag.

LAGOS, N., ONODERA, H., ZAGATTO, PA., ANDRINOLO, D., AZEVEDO, SMFQ. and OSHIMA, Y., 1999. The first evidence of paralytic shellfish toxins in the freshwater cyanobacterium Cylindrospermopsis raciborskii, isolated from Brazil. Toxicon, vol. 37, no. 10, p. 1359-1373. http://dx.doi.org/10.1016/S00410101(99)00080-X

LIRA, GAST., ARAÚJO, EL., BITTENCOURT-OLIVEIRA, MC. and MOURA, AN., 2011. Phytoplankton abundance, dominance and coexistence in an eutrophic reservoir in the state of Pernambuco, northeast Brazil. Anais da Academia Brasileira de Ciências, vol. 83, no. 4. http://dx.doi.org/10.1590/S000137652011000400018

LOBO, E. and LEIGHTON, G., 1986. Estructuras comunitarias de las fitocenosis planctonicas de los sistemas de desembocaduras de rios y esteros de la zona central de Chile. Revista de Biologia Marinha, vol. 22, p. 1-29.

MACK, RN., SIMBERLOFF, D., LONSDALE, WM., EVANS, H., CLOUT, M. and BAZZAZ, FA., 2000. Biotic invasions: causes, epidemiology, global consequences and control. Ecological Applications, vol. 10, p. 689-710. http://dx.doi.org/10.1890/10510761(2000)010[0689:BICEGC]2.0.CO;2

MOLISANI, MM., BARROSO, HS., BECKER, H., MOREIRA, MOP., HIJO, CAG., MONTE, TM. and VASCONCELLOS, GH., 2010. Trophic state, phytoplankton assemblages and limnological diagnosis of the Castanhão Reservoir, CE, Brazil. Acta Limnologica Brasiliensia, vol. 22, no. 1, p. 1-12.

MOURA, AN., DANTAS, EW., OLIVEIRA, HSB. and BITTENCOURT-OLIVEIRA, MC., 2011. Vertical and temporal dynamics of cyanobacteria in the Carpina potable water reservoir in northeastern Brazil. Brazilian Journal of Biology, vol. 71, no. 2, p. 451-459. http://dx.doi.org/10.1590/S1519-69842011000300015

NASELLI-FLORES, L., 2000. Phytoplankton assemblages in twenty-one Sicilian reservoirs: relationships between species composition and environmental factors. Hydrobiologia, vol. 424, no. 1-3, p. 1-11. http://dx.doi.org/10.1023/A:1003907124528

NIXDORF, B., MISCHKE, J. and RÜCKER, U., 2003. Phytoplankton assemblages and steady state in deep and shallow eutrophic lakes - an approach to differentiate the habitat properties of Oscillatoriales. Hydrobiologia, vol. 502, no. 1-3, p. 111-121. http://dx.doi.org/10.1023/B:HYDR.0000004274.65831.e5

PADISÁK, J. 1997. Cylindrospermopsis raciborskii (Woloszynska) Seenayya et Subba Raju, an expanding, highly adaptative cyanobacterium: worldwide distribution and review of its ecology. Archiv Für Hydrobiologie, vol. 107, p. 563-593.

PADISÁK, J. and REYNOLDS, CS., 1998. Selection of phytoplankton associations in Lake Balaton, Hungary, in response to eutrophication and restoration measures, with special reference to the cyanoprokaryotes. Hydrobiologia, vol. 384, no. 1-3, p. 41-53.

PANOSSO, R., COSTA, IAS., SOUZA, NR., ATTAYDE, JL., CUNHA, SRS. and GOMES, FCF., 2007. Cianobactérias e Cianotoxinas em Reservatórios do Estado do Rio Grande do Norte e o Potencial Controle das Florações pela Tilápia do Nilo (Oreochromis niloticus). Oeocologia Brasiliensis, vol. 11, no. 3, p. 433-449. http://dx.doi.org/10.4257/oeco.2007.1103.12

Pernambuco (Estado). Secretaria de Recursos Hídricos de Pernambuco - SRH, 2000. Plano Estadual de Recursos Hídricos do Estado de Pernambuco - Documento Síntese. Recife.

POMATI, F., SACCHI, S., ROSSETI, C., GIOVANNARDI, S., ONODERA, H., OSHIMA, Y. and NEILAN, BA., 2000. The freshwater cyanobacterium Planktothrix sp. FP1: Molecular identification and detection of paralytic shellfish poisoning toxins. Journal of Phycology, vol. 36, no. 3, p. 553-562. http://dx.doi. org/10.1046/j.1529-8817.2000.99181.x

POULICKOVA, A., HASLER, P. and KITNER, M., 2004. Annual cycle of Planktothrix agardhii (Gom.) Anagn. \& Kom. nature population. International Review of Hydrobiology, vol. 89, no. 3, p. 278-288. http://dx.doi.org/10.1002/iroh.200310716

REYNOLDS, CS., HUSZAR, V., KRUK, C., NASELLI-FLORES, L. and MELO, S., 2002. Towards a functional classification of the freshwater phytoplankton. Journal of Plankton Research, vol. 24, no. 5, p. 417-428. http://dx.doi.org/10.1093/plankt/24.5.417

RÜCKER, J., WIEDNER, C. and ZIPPEL, P., 1997. Factors controlling the dominance of Planktothrix agardhii and Limnothrix redekei in eutrophic shallow lakes. Hydrobiologia, vol. 342-343, no. 1-3, p. 107-115.

SAKER, ML., NOGUEIRA, ICG., VASCONCELOS, VM., NEILAN, BA., EAGLESHAM, GK. and PEREIRA, P., 2003. First report and toxicological assessment of the cyanobacterium Cylindrospermopsis raciborskii from Portuguese freshwaters. Ecotoxicology and Environmental Safety, vol. 55, no. 2, p. 243-250. http://dx.doi.org/10.1016/S0147-6513(02)00043-X

SCHEFFER, M., RINALDI, S., GRAGNANI, A., MUR, LR. and VAN NES, EH., 1997. On the dominance of filamentous cyanobacteria in shallow, turbid lakes. Ecology, vol. 78, no. 1, p. 272-282. http://dx.doi.org/10.1890/0012-9658(1997)078[0272:OT DOFC]2.0.CO;2 
STRICKLAND, JDH. and PARSONS, TR., 1965. A manual of sea water analysis. Bulletin Fisheries Research Board of Canada, vol. 125, p. 1-185.

TER BRAAK, CJE. and SMILAVER, P. 1998. CANOCO reference manual and user's guilde to CANOCO for windows. Wageningen: Centre for Biometry. 351 p.

TOLEDO JUNIOR, AP., TALARICO, M., CHINEZ, SJ. and AGUDO, EG., 1983. A aplicação de modelos simplificados para a avaliação de processo da eutrofização em lagos e reservatórios tropicais. In Anais do Congresso Brasileiro de Engenharia Sanitária e Ambiental, 1983. p. 1-34.
UTERMÖHL, H., 1958. Zur vervollkommnung der quantitativen phytoplankton-methodik. Mitteilungen Internationale Vereiningung fuer Theoretische und Angewandte Limnologie, vol. 9, p. 1-38.

VALDERRAMA, G.C., 1981. The simultaneous analysis of total nitrogen and total phosphorus in natural waters. Marine Chemistry, vol. 10, p. 109-122. http://dx.doi.org/10.1016/03044203(81)90027-X

WOOD, RB., ROSSER, MV. and BATER, RM. 1976. The seasonal pattern of thermal characteristics of four of the Bishoftu crater lakes, Ethiopia. Freshwater Biology, vol. 6, no. 6, p. 519-530. http://dx.doi.org/10.1111/j.1365-2427.1976.tb01643.x 